\title{
PENGARUH INDEKS KEBERLANJUTAN PERKEBUNAN KELAPA SAWIT TERHADAP PENDAPATAN MASYARAKAT SEKITAR DI KALIMANTAN TENGAH
}

\author{
THE INFLUENCE OF THE SUSTAINABILITY INDEX OF PALM OIL PLANTATION \\ ON THE INCOME OF THE LOCAL COMMUNITY \\ IN CENTRAL KALIMANTAN
}

${ }^{1}$ Yuprin A.D, ${ }^{2}$ Agus Yuniawan Isyanto
${ }^{1}$ Staf Pengajar Program Studi Agribisnis, Fakultas Pertanian, Universitas Palangka Raya
${ }^{2}$ Staf Pengajar Program Studi Agribisnis, Fakultas Pertanian, Universitas Galuh e-mail: yuprinad@agb.upr.ac.id

\begin{abstract}
ABSTRAK
Penelitian ini bertujuan menganalisis pengaruh indeks keberlanjutan perkebunan kelapa sawit bersama faktor lainnya terhadap pendapatan masyarakat sekitar. Sampel penelitian adalah perusahaan perkebunan kelapa sawit yang dipilih secara sengaja berdasarkan bagian Daerah Aliran Sungai dan sampel masyarakat sekitar yang dipilih secara acak dalam kelompok wilayah ring satu. Data dianalisis dengan menggunakan regresi berganda dengan variabel terikat, yakni pendapatan dan variabel bebas, yakni umur kepala keluarga, pendidikan kepala keluarga, jumlah anggota keluarga, jumlah sumber pendapatan dan indeks keberlanjutan perusahaan perkebunan kelapa sawit. Hasil penelitian menunjukkan bahwa umur, pendidikan dan indeks keberlanjutan perusahaan perkebunan kelapa sawit berpengaruh positif dan signifikan terhadap tingkat pendapatan rumah tangga di sekitar perusahaan perkebunan kelapa sawit, sedangkan jumlah anggota rumah tangga dan jumlah sumber pendapatan tidak berpengaruh signifikan terhadap tingkat pendapatan rumah tangga. Pengaruh signifikan indeks keberlanjutan perusahaan perkebunan kelapa sawit terhadap tingkat pendapatan rumah tangga di sekitarnya menunjukkan bahwa semakin tinggi indeks keberlanjutan perkebunan kelapa sawit, maka semakin tinggi pula pendapatan masyarakat di sekitarnya.
\end{abstract}

Kata kunci: Indeks keberlanjutan, pendapatan, pengaruh, perusahaan perkebunan, masyarakat sekitar

\section{ABSTRACT}

This study aims to analyze the influence of the sustainability index of palm oil plantations along with other factors on the income of the local community in Central Kalimantan. The research sample was oil palm plantation companies which were purposively selected based on the watershed area and the sample of the local communities were randomly selected in the ring one region group. Data were analyzed using multiple linear regression equations with the dependent variable, namely income and independent variables, namely the age of the family head, the education of the family head, the number of family members, the number of income sources and the sustainability index of the oil palm plantation companies. The results showed that age, education and sustainability index of palm oil plantation companies had a positive and significant effect on household income levels of local community, while the number of household members and the number of sources of income did not significantly influence the level of household income level. Significant influence of the sustainability index 
of palm oil plantation companies on household income levels indicates that the higher the sustainability index of the palm oil plantation, the higher the income of local communities.

Keywords: Income, influence, local communities, plantation companies, sustainability index

\section{PENDAHULUAN}

Perkebunan kelapa sawit di Indonesia merupakan salah penyumbang Produk Domestik Bruto (PDB) Negara Indonesia. Nilai ekspor dari produksi perkebunan kelapa sawit pada tahun 2015 adalah berjumlah US\$ 15.385.275.000 atau setara Rp. 200 triliun (asumsi US\$1 = Rp 13.000) atau 2,23\% dari nilai PDB yang berjumlah Rp. 8.982,51 triliun. Selain itu, perkebunan kelapa sawit mampu menyerap tenaga kerja sebanyak 3,4 juta orang (Dirjenbun, 2016).

Luas areal tanaman perkebunan kelapa sawit pada tahun 2015 di Kalimantan Tengah mencapai 1.142.004 ha atau $10,14 \%$ dari total luas areal tanaman perkebunan kelapa sawit di Indonesia, yakni seluas 11.260.277 ha. Areal tanaman perkebunan kelapa sawit pada tahun 2012 adalah seluas 1.164.009,41 ha dan meningkat pada tahun 2016 meningkat menjadi 1.495.605,89 ha. Periode ini juga terjadi peningkatan produksi dari 3.200.920,15 ton pada tahun 2012 menjadi 4.485.167,20 ton pada tahun 2016 (Anonim, 2017). Artinya pada periode tersebut terjadi peningkatan luas areal sebesar $28,49 \%$ dan peningkatan produksi sebesar $40,12 \%$.

Peningkatan luas areal dan produksi tercipta dari hasil pembangunan perkebunan kelapa sawit di Kalimantan Tengah yang memiliki pengaruh terhadap kehidupan sosial ekonomi masyarakat sekitar pada umumnya dan pendapatan masyarakat sekitar pada khususnya. Hal ini diungkapkan oleh salah satu pemerhati, yakni Rony, dkk. (2013), Ruslan (2014), Rusmawardi (2014) dan Laing (2016).

Hasil penelitian Rony, dkk., Ruslan dan Laing menunjukkan bahwa perkebunan kelapa sawit berdampak positif terhadap pendapatan masyarakat lokal.
Hasil penelitian penelitian Rony, dkk. (2013) dan Ruslan (2014), menyatakan bahwa telah mampu menigkatkan pendapatan masyarakat. Demikian juga hasil penelitian Laing menunjukkan bahwa sejak adanya kegiatan perkebunan di Desa Badak Mekar memberikan peluang pekerjaan bagi penduduk di area sekitar perkebunan, hal tersebut ternyata memberikan dampak positif bagi pendapatan masyarakat.

Hasil penelitian ke tiga peneliti di atas sesuai dengan apa yang diharapkan dalam salah satu Undang-undang nomor 18 Tahun 2004 pasal 2 yang menyatakan bahwa perkebunan diselenggarakan bedasarkan atas asas manfaat dan berkelanjutan, keterpaduan, kebersamaan, keterbukaan, serta berkeadilan. Tujuan perkebunan kelapa sawit adalah untuk meningkatkan pendapatan masyarakat lokal, daerah, dan negara, serta menciptakan lapangan kerja untuk sebesarbesarnya kesejahtraan rakyat. Hasil penelitian kedua peneliti di atas menunjukkan bahwa keberadaan atau eksistensi perusahaan perkebunan kelapa sawit tersebut berpengaruh terhadap pendapatan masyarakat di sekitarnya.

Agunggunanto (2011), menyatakan bahwa pendapatan masyarakat atau rumah tangga di Kecamatan Wedung Kabupaten Demak, Jawa Tengah dipengaruhi secara positif oleh jumlah anggota keluarga yang bekerja, kemudian hasil penelitian Lhing, et al. (2013) megungkapkan bahwa salah satu faktor sosial ekonomi rumah tangga di Myanmar yang paling penting adalah tingkat pendidikan, selain itu ditentukan juga oleh umur, luas lahan dan jumlah usahatani.

Menurut penelitian Teame dan Woldu (2016) menunjukkan bahwa usia atau umur rumah tangga dan pendidikan berpengaruh positif terhadap pendapatan 
rumah tangga pada ke-4 desa di Zoba Maekel, Eritrea. Selanjutnya Budiartiningsih, et al. (2010) menyatakan bahwa pendapatan rumah tangga dapat berasal lebih dari sektor non usahatani/informal memiliki kontribusi yang besar terhadap peningkatan pendapatan keluarga petani. Sumber pendapatan yang beragam tersebut terjadi karena anggota rumah tangga yang bekerja melakukan lebih dari satu jenis kegiatan.

Menurut hemat penulis adalah bahwa selain umur, pendidikan, jumlah anggota keluarga, jumlah anggota keluarga yang bekerja dan jumlah sumber pendapatan yang mempengaruhi pendapatan rumah tangga, eksistensi perusahaan perkebunan kelapa sawit juga diduga berpengaruh terhadap tingkat pendapatan masyarakat di sekitarnya. Menurut Dehen, et al. (2013) bahwa eksistensi perusahaan perkebunan kelapa sawit secara kuantitatif diukur dengan indeks keberlanjutannya. Indeks keberlanjutan merupakan nilai yang menentukan tingkat atau status keberlanjutan perkebunan kelapa sawit yang nilainya mulai 0 sampai dengan $100 \%$. Masyarakat sekitar/lokal adalah masyarakat yang bermukim dekat dengan lokasi perkebunan kelapa sawit dan terkena dampak langsungnya atau sering dinamakan dengan ring satu, dalam satuan desa. Untuk memastikan pengaruh eksistensi perusahaan perkebunan kelapa sawit secara kuantitatif terhadap pendapatan masyarakat sekitar, penelitian ini bertujuan menganalisis pengaruh indeks keberlanjutan perkebunan kelapa sawit bersama faktor lainnya (umur, pendidikan, jumlah anggota keluarga, jumlah anggota keluarga yang bekerja dan jumlah sumber pendapatan) terhadap pendapatan masyarakat sekitar.

\section{METODE PENELITIAN}

Tempat penelitian ditentukan secara sengaja di Kabupaten Kotawaringin Barat, Kalimantan Tengah karena merupakan salah satu kabupaten sebagai penyumbang terbesar $(35,72 \%)$ terhadap produksi sawit di Kalimantan Tengah. Penelitian ini menggunakan metode survei, yaitu penelitian untuk memperoleh fakta dan mengenal masalah-masalah serta mendapatkan pembenaran terhadap praktik-praktik yang sedang berlangsung oleh unit tertentu dalam suatu tempat dan waktu tertentu dengan sampel (Nazir, 2005).

Sampel, meliputi perusahaan perkebunan kelapa sawit (PPKS) dan rumah tangga yang bermukim di desa (di dalam dan di luar kawasan PPKS). PPKS sampel dipilih berdasarkan posisinya dalam daerah aliran sungai (DAS), meliputi bagian hulu (1 dan 2), tengah (3 dan 4) dan hilir (5 dan 6). Desa sampel di dalam kawasan PPKS disesuaikan dengan jaraknya terhadap perusahaan sampel, yakni desa yang dikategorikan oleh perusahaan sebagai ring satu (terdekat), sedangkan desa di luar kawasan PPKS dipilih desa yang terletak sangat jauh dan dianggap tidak dipengaruhi oleh PPKS. Sampel terkecil berikutnya adalah sampel rumah tangga dalam unit satu keluarga atau kepala keluarga $(\mathrm{KK})$ yang dipilih secara acak sederhana, yakni setiap rumah tangga dalam populasi tertentu mendapat peluang yang sama untuk dipilih. Jumlah sampel ditetapkan sebanyak 134 rumah tangga dengan prosedur penentuan sampel (n) menurut Parel, et al. (1973) sebagai berikut:

$$
n=\frac{N Z^{2} \sigma^{2}}{N d^{2}+Z^{2} \sigma^{2}}
$$

Keterangan:

$N=$ jumlah populasi

$Z=$ Konstanta yang diperoleh dari tabel normal baku pada derajat kepercayaan yang dikehendaki (95\%)

$\sigma^{2}=$ varians populasi

$d=$ bound of error yang ditolerir/dikehendaki $(0,10)$ 
Varians populasi belum diketahui sehingga ditaksir menggunakan varians sampel $\left(s^{2}\right)$ dengan rumus:

$$
s^{2}=\frac{\sum\left(x_{i}-\bar{x}\right)^{2}}{n-1}
$$

Keterangan:

$x_{i}=$ luas lahan yang dikelola oleh petani ke-i (ha)

$i=1,2,3, . ., 35$

Sehingga rumus di atas menjadi:

$$
n=\frac{N Z^{2} s^{2}}{N d^{2}+Z^{2} s^{2}}
$$

Keterangan:

$N=$ jumlah populasi

$Z=$ konstanta yang diperoleh dari tabel normal baku pada derajat kepercayaan yang dikehendaki $(95 \%)$

$s^{2}=$ varians sampel luas lahan

$d=$ bound of error yang ditolerir/dikehendaki $(0,10)$

Berdasarkan varians dari 35 sampel, diperoleh jumlah sampel sebanyak 134 rumah tangga yang ada di dalam kawasan PPKS dan 33 rumah tangga di luar kawasan PPKS. Lebih rinci jumlah sampel masing-masing desa $\left(\mathrm{n}_{\mathrm{h}}\right)$, ditentukan dengan rumus:

Keterangan:

$$
n_{h}=\frac{n}{N} \cdot N_{h}
$$

$n=$ total sampel

$N=$ jumlah populasi

$N_{h}=$

Data yang diperlukan adalah pendapatan rumah tangga, umur kepala keluarga, pendidikan kepala rumah tangga, jumlah anggota rumah tangga, jumlah sumber pendapatan dan indeks keberlanjutan perusahaan perkebunan kelapa sawit.

Pendapatan rumah tangga adalah jumlah penghasilan bersih dari seluruh anggota rumah tangga yang disumbangkan untuk memenuhi kebutuhan bersama maupun perseorangan dalam rumah tangga (Rp/tahun). Penghasilan bersih atau pendapatan merupakan selisih penghasilan dengan biaya yang dikorbankan untuk memperoleh penghasilan dimaksud (Rp/tahun). Umur adalah umur kepala keluarga yang diukur dalam satuan tahun. Pendidikan adalah pendidikan formal yang pernah diikuti oleh kepala keluarga yang diukur dalam satuan tahun. Jumlah anggota keluarga adalah banyaknya anggota keluarga yang ada dalam satu rumah tangga yang bersangkutan dan diukur dalam satuan orang. Jumlah sumber pendapatan merupakan pekerjaan yang ditekuni oleh suatu rumah tangga untuk mengasilkan pendapatannya dan diukur dalam satuan unit. Indeks keberlanjutan merupakan nilai indeks keberlanjutan masing-masing perusahaan perkebunan kelapa sawit yang disesuaikan dengan responden pada masing-masing desa, diukur dalam satuan persen (\%).

Metode analisis data untuk menganalisis faktor-faktor yang berpengaruh terhadap tingkat pendapatan rumah tangga di sekitar perusahaan perkebunan kelapa sawit, dilakukan dengan menggunakan metode regresi berganda, dengan model persamaan sebagai berikut:

$Y=a+b_{1} X_{1}+b_{2} X_{2}+b_{3} X_{3}+b_{4} X_{4}+b_{5} X_{5}+e$

Keterangan:

$\mathrm{Y}=$ pendapatan rumah tangga (Rp/tahun)

$\mathrm{X}_{1}=$ umur kepala keluarga (tahun)

$\mathrm{X}_{2}=$ pendidikan kepala keluarga (tahun)

$\mathrm{X}_{3}=$ jumlah anggota keluarga (orang) populasi masing-m

$\mathrm{X}_{4}=$ jumlah sumber pendapatan (unit)

$\mathrm{X}_{5}=$ indeks keberlanjutan perusahaan perkebunan kelapa sawit (\%)

$\mathrm{b}_{1-5}=$ koefisien regresi variabel $\mathrm{X}_{1-5}$

\section{HASIL DAN PEMBAHASAN}

Hasil dan pembahasan hasil penelitian akan dikemukakan sebagai berikut. 
Tabel 1.Hasil Analisis Regresi FaktorFaktor yang Mempengaruhi Pendapatan Rumah Tangga di Sekitar Perusahaan Perkebunan Kelapa Sawit di Kalimantan Tengah

\begin{tabular}{|c|c|c|c|c|}
\hline No. & Variabel Bebas & $\begin{array}{l}\text { Koefiisien } \\
\text { Regresi }\end{array}$ & t-sig & SCB \\
\hline 1 & Konstanta & 172.082 & 0,955 & \\
\hline 2 & Umur & $\left.281.937^{* * *}\right)$ & 0,000 & 0,762 \\
\hline 3 & Pendidikan & $554.507^{* * *)}$ & 0,000 & 0,491 \\
\hline 4 & $\begin{array}{l}\text { Jumlah anggota } \\
\text { keluarga }\end{array}$ & 59.365 & 0,822 & 0,029 \\
\hline 5 & $\begin{array}{l}\text { Jumlah sumber } \\
\text { pendapatan }\end{array}$ & 709.591 & 0,113 & 0,317 \\
\hline 6 & $\begin{array}{l}\text { Indeks } \\
\text { keberlanjutan }\end{array}$ & $46.500^{* * * *}$ & 0,000 & 0,620 \\
\hline \multicolumn{3}{|c|}{ F-sig $=0,000$} & \multicolumn{2}{|c|}{ Adj. $R^{2}=0,515$} \\
\hline
\end{tabular}

Keterangan:

${ }^{* * *)}=$ signifikan pada taraf kepercayaan $99 \%$

Sumber: Hasil analisis data.

Tabel 1 menunjukkan bahwa nilai F-sig $=0,000$ berarti model regresi tersebut telah layak digunakan, dengan taraf kepercayaan 99\%. Demikian juga apabila dilihat dari nilai $\mathrm{R}^{2}=0,515$, wajarlah karena ada dua variabel bebas yang tidak signifikan, yaitu variabel jumlah anggota keluarga dan jumlah sumber pendapatan, sehingga multikolinearitas dapat diabaikan. Oleh karena itu model tersebut di atas sudah dianggap layak untuk diinterpretasikan lebih lanjut.

Kemampuan model tersebut menjelaskan bahwa pengaruh umur, pendidikan, jumlah anggota keluarga, jumlah sumber pendapatan dan indeks keberlanjutan perkebunan kelapa sawit terhadap tingkat pendapatan rumah tangga di sekitar perusahaan perkebunan kelapa sawit adalah sebesar $51,50 \%$ sedangkan sisanya $(48.50 \%)$ dipengaruhi oleh faktor lain yang tidak termasuk di dalam model.

Berdasarkan uji statistik $\mathrm{t}$ (uji parsial), yaitu dengan mengacu kepada nilai t-sig, menunjukkan bahwa umur, pendidikan, jumlah anggota rumah tangga, jumlah sumber pendapatan dan indeks keberlanjutan perusahaan perkebunan kelapa sawit berpengaruh positif terhadap tingkat pendapatan rumah tangga di sekitar perusahaan perkebunan kelapa sawit, namun jumlah anggota rumah tangga dan jumlah sumber pendapatan berpengaruh tidak nyata terhadap tingkat pendapatan rumah tangga.

Interpretasi masing-masing faktor yang berpengaruh nyata terhadap pendapatan rumah tangga di sekitar perusahaan perkebunan kelapa sawit adalah sebagai berikut:

1. Umur kepala keluarga berpengaruh nyata terhadap tingkat pendapatan rumah tangga di sekitar perkebunan kelapa sawit pada taraf kepercayaan 99\%. Artinya apabila umur kepala keluarga lebih tua, maka tingkat pendapatannya juga menjadi lebih tinggi dibandingkan rumah tangga yang kepala keluarga berumur lebih muda.

2. Pendidikan kepala keluarga berpengaruh nyata terhadap tingkat pendapatan rumah tangga di sekitar perkebunan kelapa sawit pada taraf kepercayaan 99\%. Artinya apabila pendidikan formal kepala keluarga lebih tinggi, maka tingkat pendapatannya juga menjadi lebih tinggi dibandingkan rumah tangga yang kepala keluarganya berpendidikan lebih rendah.

3. Indeks keberlanjutan perusahaan perkebunan kelapa sawit berpengaruh nyata terhadap tingkat pendapatan rumah tangga di sekitarnya pada taraf kepercayaan 99\%. Artinya apabila indeks keberlanjutan suatu perusahaan perkebunan kelapa sawit lebih tinggi, maka tingkat pendapatan rumah tangga di sekitarnya juga menjadi lebih tinggi dibandingkan rumah tangga di sekitar perusahaan perkebunan kelapa sawit yang memiliki indeks keberlanjutan lebih rendah.

Pengaruh masing-masing faktor umur, pendidikan, jumlah anggota keluarga, jumlah sumber pendapatan dan indeks keberlanjutan perkebunan kelapa sawit terhadap tingkat pendapatan rumah tangga di sekitarnya, memiliki besar yang 
berbeda-beda. Besar pengaruh dimaksud, dapat dilihat dari Standardized Coefficients Beta (SCB). Apabila nilai SCB semakin besar, maka semakin besar pengaruh faktor yang bersangkutan (variabel bebas) terhadap pendapatan rumah tangga di sekitar perkebunan kelapa sawit (variabel terikat). Dengan demikian, atas dasar nilai SCB menunjukkan bahwa indeks keberlanjutan perusahaan perkebunan kelapa sawit memiliki pengaruh terbesar kedua terhadap tingkat pendapatan rumah tangga di dalam kawasan perusahaan, sebaliknya jumlah anggota keluarga memiliki pengaruh terkecil.

Hal yang dianggap penting dari hasil penelitian ini adalah bahwa disamping faktor-faktor umum yang telah diteliti oleh peneliti sebelumnya (seperti: umur, pendidikan, jumlah anggota keluarga dan jumlah sumber pendapatan), ternyata indeks keberlanjutan perusahaan perkebunan kelapa sawit di lokasi penelitian juga sangat menentukan tingkat pendapatan rumah tangga yang bermukim di sekitarnya. Hal ini disebabkan karena sebagian masyarakat lokal bekerja sebagai karyawan di perusahaan tersebut, sebagian sebagai petani plasma, sebagai pedagang pengumpul TBS yang kemudian menjualnya kepada perusahaan dan sebagian dapat menjual produksinya kepada rumah tangga karyawan di perusahaan perkebunan kelapa sawit.

\section{KESIMPULAN}

Berdasarkan hasil penelitian dan pembahasan, dapat disimpulkan bahwa selain umur, pendidikan, jumlah anggota keluarga dan jumlah sumber pendapatan, ternyata indeks keberlanjutan perusahaan perkebunan kelapa sawit berpengaruh nyata secara positif terhadap tingkat pendapatan rumah tangga di sekitarnya.

\section{DAFTAR PUSTAKA}

Agunggunanto, E.Y. (2011). Analisis Kemiskinan dan Pendapatan
Keluarga Nelayan Kasus di Kecamatan Wedung Kabupaten Demak, Jawa Tengah-Indonesia. Jurnal Dinamika Ekonomi Pembangunan, 1: 50-58.

Anonim. (2017). Provinsi Kalimantan Tengah Dalam Angka 2017. Palangka Raya: Badan Pusat Statistik Provinsi Kalimantan Tengah.

Budiartiningsih, R., Maulida, Y., Taryono. (2010). Faktor-Faktor yang Mempengaruhi Peningkatan Pendapatan Keluarga Petani Melalui Sektor Informal di Desa Kedaburapat, Kecamatan Rangsang Barat, Kabupaten Bengkalis. Jurnal Ekonomi, 18: 79-93.

Dehen, Y.A., Mustadjab, M.M., Setiawan, B., Anindita, R. (2013). Sustainability Analysis of Palm Oil Plantation in Central Kalimantan Province, Indonesia. Journal of Economics and Sustainable Development, 4: 175-182.

Direktorat Jenderal Perkebunan. (2016). Statistik Perkebunan Indonesia 2015-2017 Kelapa Sawit. Jakarta: Sekretariat Direktorat Jenderal Perkebunan, Direktorat Jenderal Perkebunan, Kementerian Pertanian.

Laing. (2016). Dampak Keberadaan Perkebunan Kelapa Sawit Terhadap Kondisi Sosial Ekonomi Masyarakat Desa di Desa Badak Mekar, Kecamatan Muara Badak, Kabupaten Kutai Kartanegara. Journal Ilmu Pemerintahan, 4: 633646.

Lhing, N.N., Nanseki T., Takeuchi, S. (2013). An Analysis of Factors Influencing Household Income: A Case Study of PACT Microfinance in Kyaukpadaung Township of Myanmar. American Journal of Human Ecology, 2: 94-102.

Nazir, M. (2005). Metode Penelitian. Bogor: Ghalia Indonesia. 
Parel, C.P., Caldito, G.C., Ferrer, P.L., De Guzman, G.G., Sincioco, C.S., Tan, R.H. (1973). Sampling Design and Procedures. Trial Edition. Quezon City: PSSC Social Survey Series 1.

Rony, Sativa, F., Suratno, T. (2013). Dampak Perusahaan Perkebunan Kelapa Sawit Terhadap Perubahan Kebudayaan Masyarakat Desa Mekar Sari Kecamatan Kumpeh Kabupaten Muaro Jambi Provinsi Jambi. Sosio Ekonomika Bisnis, 1: 10-17.
Ruslan, I. (2014). Perubahan Sosial dan Ekonomi Masyarakat Akibat Perkebunan Kelapa Sawit. AlMaslah Jurnal Ilmu Syariah, 9: 3251.

Teame, G.T., Woldu, T.Y.M. (2016). Factors Affecting Rural Households Income Diversification: Case of Zoba Maekel, Eritrea. American Journal of Business, Economics and Management, 4: 7-15. 